\title{
Litter-fall and decomposition in harvested and un-harvested boreal forests
}

\author{
by M.T. Moroni ${ }^{1,2}$ and X. Zhu ${ }^{1}$
}

\begin{abstract}
Litter fall and litter decomposition were examined in harvested and unharvested western Newfoundland balsam fir (Abies balsamea) and black spruce (Picea mariana) forests. Rates of litterfall in mature 70-year-old forests were 2.4 to $3.5 \mathrm{Mg} \mathrm{ha}^{-}$ ${ }^{1}$ year $^{-1}$, which was reduced to 0.2 to $0.3 \mathrm{Mg} \mathrm{ha}^{-1}$ year $^{-1}$ following harvesting. In contrast, rates of black spruce needle, balsam fir needle, fine ( $<2 \mathrm{~mm}$ diameter) root, and moss (dominated by feather moss) litter decomposition were not affected by forest harvesting at either site during 24 to 54 months of field incubation in litterbags. Mass loss of balsam fir needle, black spruce needle, and moss (dominated by feather moss) were not significantly different indicating that moss forms a labile litter type in a forested setting.
\end{abstract}

Key words: moss, black spruce (Picea mariana), balsam fir (Abies balsamea), Newfoundland, Canada

\section{RÉSUMÉ}

La chute et la décomposition de la litière ont été étudiées dans des peuplements exploités et non-exploités de sapin (Abies balsamea) et dépinette noire (Picea mariana) dans louest de Terre-Neuve. Les taux de chute de litière dans les peuplements mûrs de 70 ans variaient de 2,4 à $3,5 \mathrm{Mg} \mathrm{ha}^{-1} \mathrm{an}^{-1}$, lesquels ont été réduits à 0,2 à $0,3 \mathrm{Mg} \mathrm{ha}^{-1} \mathrm{an}^{-1}$ après récolte. Par contre, les taux de décomposition de la litière des aiguilles dépinette noire, des petites $(<2 \mathrm{~mm}$ de diamètre $)$ racines et de la mousse (principalement l'hypne) n’ont pas été affectés par l'exploitation forestière sur aucun des sites au cours des 24 à 54 mois d'incubation sur place dans des sacs de litière. Les pertes en termes de masse d'aiguilles de sapin, d'aiguilles d’épinette et de mousse (prépondérance de l'hypne) nont pas été significativement différentes indiquant que la mousse forme un type de litière instable dans un environnement forestier.

Mots clés : mousse, épinette noire (Picea mariana), sapin baumier (Abies balsamea), Terre-Neuve, Canada

\section{Introduction}

As atmospheric carbon dioxide $\left(\mathrm{CO}_{2}\right)$ levels and temperatures rise, understanding the effects of anthropogenic forest disturbance on the forest carbon (C) cycle and fluxes of $\mathrm{C}$ with the atmosphere is increasingly important. Boreal forests, which represent one of the Earth's largest biomes, contain an enormous amount of soil carbon (Tarnocai et al. 2009). In the wet eastern Canadian boreal forests of Newfoundland, forests are dominated by balsam fir (Abies balsamea [L.] Mill): fir) and black spruce (Picea mariana [Mill.] BSP): spruce), cover types common to large areas of northern North America.

The major anthropogenic disturbance in spruce and fir is clearcut harvesting; approximately 17500 ha have been clearcut annually in Newfoundland in recent years (NLDFRA 1998), yet little is known of litter cycles in these forests and less on the impacts of forest management on litter cycles. There is a lack of understanding of the effect of forest harvesting on the C cycle (Howard et al. 2004), necessitating research to quantify the impact of harvesting on a range of sites.
Litter production is a key source of soil organic matter. Input of fresh organic matter supports decomposer communities that drive below-ground carbon and nutrient cycles. Decomposition of residual organic matter continues after the cessation of litter inputs, depleting detrital soil C stores. While rates of litterfall are available for boreal and northern coniferous forests (Bray and Gorham 1964, Prescott et al. 1989, Nakane et al. 1997), rates of litterfall from Newfoundland coniferous forests are not documented and there is a dearth of such information in balsam fir forests.

Clearcutting clearly alters litter cycles, reducing overstory litter inputs following harvesting, but its effect on litter decomposition is more complex. Clearcutting generally increases soil temperatures and often improves soil moisture levels, both of which are expected to increase rates of litter decomposition. However, while increased rates of litter decomposition have been reported following clearcutting, no increase is more commonly reported (Table 1). Hence, the effects of clearcutting on rates of litter decomposition are site-

\footnotetext{
${ }^{1}$ Natural Resources Canada, Canadian Forest Service, Atlantic Forestry Centre, PO Box 960 Corner Brook, Newfoundland and Labrador A2H 6J3.

${ }^{2}$ Current address: Forestry Tasmania, 79 Melville Street, Hobart, Tasmania, 7000, Australia. E-mail: Martin.Moroni@forestrytas.com.au
} 
Table 1. Published response in rates of litter decomposition to forest clearfelling

\begin{tabular}{|c|c|c|c|}
\hline Response & Forest type & Location & Reference \\
\hline \multicolumn{4}{|l|}{ Increase } \\
\hline & Pinus radiata ${ }^{\text {a }}$ & New Zealand & Gadgil and Gadgil 1978 \\
\hline & Pinus ponderosa & Arizona & Klemmedson et al. 1985 \\
\hline & Picea glauca & Alaska & Piene and van Cleve 1978 \\
\hline & Pinus contorta & Alberta & Taylor et al.1991, Prescott et al. 1993 \\
\hline \multicolumn{4}{|r|}{ 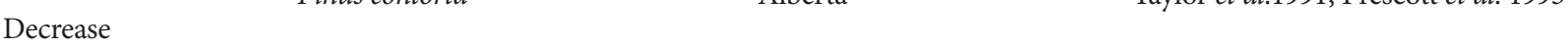 } \\
\hline & Quercus, Carya and Acer species & North Carolina & Blair and Crossley 1988 \\
\hline & Pinus radiata ${ }^{\text {a }}$ & Spain & Cortina and Vallejo 1994 \\
\hline & various & British Columbia & Prescott et al. 2000 \\
\hline & Picea abies & Germany & Schuting and Christman 1935 \\
\hline & Picea mariana & Quebec & Weetman 1965 \\
\hline & Southern hardwood & North Carolina & Whitford et al. 1981 \\
\hline & Quercussp. & Wisconsin & Yin et al. 1989 \\
\hline \multicolumn{4}{|l|}{ No change } \\
\hline & Coniferous & British Columbia & Binkley 1984 \\
\hline & Picea mariana & Labrador & Diekamp 2009 \\
\hline & Various & British Columbia & Prescott et al. 2000 \\
\hline & hardwood & Nova Scotia & Wallace and Freedman 1986 \\
\hline & Pinus radiata ${ }^{\text {a }}$ & New Zealand & Will et al. 1983 \\
\hline
\end{tabular}

${ }^{\mathrm{a}}$ plantation

specific (Binkley 1984) and Prescott et al. (2000) recommended forest carbon modellers assume no change in rates of decomposition following forest clearcutting unless there is site-specific evidence to the contrary.

When decomposition is slowed following clearcutting, it is commonly attributed to surface drying. Forest litter decomposition has been shown to slow following periods of low rainfall (Whitford et al. 1981). When decomposition is increased following clearcutting it is commonly attributed to warming from increased incident solar radiation, as microbial activity is a function of temperature (Fissore et al. 2009), and clearcutting has been shown to warm forest soils (Moroni et al. 2009).

Even though a large proportion of net primary productivity is allocated to fine roots (Agren et al. 1980) and moss (O'Connell et al. 2003) in boreal forests, moss and root decomposition have received relatively little attention, especially for moss in a forest setting. Inputs of $\mathrm{C}$ to the forest soil from fine roots are potentially greater than inputs from the above-ground biomass (Vogt et al. 1986). Root decomposition follows patterns observed for other litter types where early decomposition is regulated by nutrient content or labile soluble material, strongly influenced by leaching, and latter stages of decomposition are more strongly influenced by more complex molecules such as lignin and polyphenols (Finer et al. 1997, Preston et al. 2009). Fine roots are expected to form a labile litter source, with the decomposition of 2-mm to 3-mm roots and foliage being similar (Berg 1984).

Moss decomposition is commonly reported to be slower than vascular plant tissue decomposition in the field (Hobbie 1996, Szumigalski and Bayley 1996) and laboratory (Fyles and McGill 1987). While moss decomposition has been examined in tundra and wetlands (Hobbie et al. 2000, Thormann et al. 2001), few have examined moss decomposition in forests and moss has not been included in studies examining the impact of forest harvesting on decomposition, even though moss forms a large biomass in many boreal systems (Harden et al. 1997). Decomposition rates are slowed in peat- lands or tundra due to unfavorable (anoxic, cold, acidic or nutrient poor) environmental conditions (Szumigalski and Bayley 1996); hence, moss is likely to decompose faster in a forest environment due to improved aeration, temperature, $\mathrm{pH}$ and nutrient conditions compared to peatlands.

Our objectives were to determine the effect of forest harvesting on 1) decomposition of needles, moss, and fine roots, and 2) rates of litterfall in a balsam fir forest site and a black spruce forest site in western Newfoundland.

\section{Materials and Methods \\ Site Description}

In 2003, a study was established to examine the impact of forest clearcutting on soil temperature, moisture and respiration in two boreal forests of Newfoundland, Canada zero to three years following harvesting (Moroni et al. 2009). Within three months of clearcutting at these sites, litter traps and litter decomposition bags containing needles and moss were installed. Two years after harvesting, decomposition bags containing fine $(<2 \mathrm{~mm})$ roots were installed.

Two experimental sites (one fir, one spruce) in mature forests ( 70-year-old) that had re-grown naturally following clearcut harvesting were selected near Pasadena in western Newfoundland. The sites (fir: lat. $48^{\circ} 57^{\prime} 55^{\prime} \mathrm{N}, 63^{\circ} 37^{\prime} 49^{\prime} \mathrm{W}$; spruce: lat. $48^{\circ} 53^{\prime} 14^{\prime} \mathrm{N}, 63^{\circ} 24^{\prime} 08^{\prime} \mathrm{W}$ ) are located within the Maritime Low Boreal Ecoclimate region (Lbm) of the Ecoregions Working Group (1989), which is equivalent to the Corner Brook Section (B.28b) of the Boreal Forest Region (Rowe 1972). The sites received $1250 \mathrm{~mm}$ to $1320 \mathrm{~mm}$ annual rainfall and had a mean annual temperature of $2.5^{\circ} \mathrm{C}$ to $2.8^{\circ} \mathrm{C}$ (averages for the period 1970 to 2001 using the methods of McKenney et al. (2001)). The spruce site contained eight $50 \times$ $50-\mathrm{m}(0.25$-ha) plots. The fir site contained eight $40 \times 40-\mathrm{m}$ (0.16-ha) plots. Within each site, four plots were selected at random for harvesting, and four were unharvested, creating two treatments: forested and clearcut.

The fir site was harvested on 2-3 July 2003 and the spruce site on 7-10 July 2003, using a short-wood mechanical har- 
vester that felled, delimbed, and cut the remaining stems into 2.5-m lengths on site. All softwoods with a diameter at breast height (dbh; $1.3 \mathrm{~m}) \geq 9 \mathrm{~cm}$ were considered merchantable; some non-merchantable trees were left standing. Delimbed branches and tops were placed on the forest floor in front of the advancing harvester, forming slash piles that were generally $<1 \mathrm{~m}$ high and approximately $3 \mathrm{~m}$ wide.

The fir site was located on the side of a hill, $325 \mathrm{~m}$ to 350 $\mathrm{m}$ in elevation. Upper elevation soil was an Orthic-Humic Podzol with a $10-\mathrm{cm}$ to $12-\mathrm{cm}$ thick organic layer. Mid- and lower-slope soils were Ferro-Humic Podzols with a $3-\mathrm{cm}$ to 11-cm thick organic layer, becoming shallower down slope.

The spruce site was located next to a riparian zone for a small stream. Near to the riparian zone the soil was an Orthic Gleysol. As the distance from the riparian zone increased, the soils transitioned to a Ferro-Humic Podzol. The organic layer varied in thickness from $6 \mathrm{~cm}$ to $15 \mathrm{~cm}$.

\section{Litterfall}

Needle, leaf, wood, seed and cone, and understory litter was collected in $0.5 \times 0.5-\mathrm{m}$ square litter traps in forested and clearcut plots at the fir and spruce sites. In the centre 25 $\times 25-\mathrm{m}$ area of each plot at both sites, five litter traps were randomly installed in late May 2004, and litter that had accumulated within the traps was then collected every five to seven months for 30 months. Litter collections occurred in November before the winter snowfall accumulation, and in late May after forest access roads were passable and the forest floor was snow-free. Collected litter samples were returned to the laboratory and dried for four days at $55^{\circ} \mathrm{C}$ in a forced-air drying oven. Litter from all traps in each plot was combined, sorted into the above litter types and weighed for each collection period.

\section{Litter Decomposition}

Decomposition of balsam fir needles, black spruce needles, moss (dominated by the feathermosses; Hylocomium splendens (Hedw.) B.S.G., Pleurozium schreberi (Brid.) Mitt., Ptilium crista-castrensis (Hedw.) DeNot), and fine roots of the dominant overstory tree species at each site were examined in clearcut and forested plots at the fir and spruce sites. Litter samples were placed into $20 \times 20$-cm bags constructed from woven polypropylene fabric (Lumite style 6065400) with 0.25 $\times 0.25$-mm openings between woven polypropylene stands. Needles were collected in tarpaulins installed under trees in the study sites during the summer of 2003. Green moss tissue was harvested from the understory of forests adjacent to the study sites in the fall of 2003. Fine roots were harvested from $1 \times 1-\mathrm{m}$ samples of the organic layer above the mineral soil taken from regions adjacent to the study sites in 2004. Samples were dried at $55^{\circ} \mathrm{C}$ for four days. Individual litterbags were filled with $10 \mathrm{~g}$ of either fir needles, spruce needles, moss, or fine roots, and sewn shut with nylon thread.

Into each plot, nine litterbags per litter type, except for four litterbags for fine roots, were incubated in the field. Litterbags containing needle and moss litters were placed onto the surface of the moss layer, and fine root litterbags were placed at the boundary between the mineral and organic soils. Litterbags containing needles and moss were placed into the field on 30 October 2003. Litterbags containing fine roots were placed into the field on 30 October 2005. Moss and nee- dle litterbag collections became less frequent over time; one litterbag per litter type being collected after 7, 10, 13, 20, 25, $32,37,42$, and 54 months of field incubation. Root litterbags were collected after $7,12,19$, and 24 months of field incubation. Collected bags were cleaned, and the contents emptied into envelopes and dried at $55^{\circ} \mathrm{C}$ for four days before being weighed.

\section{Statistical Analysis}

Litterfall and litter decomposition were analyzed using linear mixed models to detect differences in mass of litterfall and mass loss during decomposition in litterbags between forest and clearcut treatments, and among litter types, annually and over the entire measurement period.

This study is a whole-plot completely randomized experimental designs with repeated measures. The litterfall experiment involved three factors: treatment (clearcut and forested) sample season (May and November collection), and year (2005 to 2007). The litter decomposition experiment also contained three factors: treatment (clearcut and forest), litter type (needle, leaf, seed, woody, understory, and total litters), and year (2004 to 2008). The candidate models derived from the litterfall experiment contain i) the fixed effects of treatments, sample season, year, and their interactions; ii) a random effect of plot-nested-within treatment. Similarly, candidate models that were associated with the litter decomposition experiment contain i) the fixed effects of treatments, litter type, year, and their interactions; ii) a random effects of plot-nested-within treatment. The final models were chosen for each experiment after testing candidate models with vs. without random effects. The overall model fit was estimated using Akaike Information Criterion (AIC). The type I error threshold was fixed at $a=0.05$. Least Squares Difference (LSD) was used to tests differences $(p<0.05)$ within subtreatments (i.e., the combinations of treatment and season for the litterfall experiment or the combinations of treatment and lit-

Table 2. Litterfall in the study sites ( $\mathrm{Mg}$ ha- ${ }^{-1}$ ). Parenthesis contain standard error, $n=4$

\begin{tabular}{lccccc}
\hline & \multicolumn{3}{c}{ Fir } & & \multicolumn{2}{c}{ Spruce } \\
\cline { 2 - 3 } \cline { 5 - 6 } & Forest & Clearcut & & Forest & Clearcut \\
\hline \multirow{2}{*}{ Summer 05 } & 1.86 & 0.14 & & 1.09 & 0.12 \\
& $(0.45)$ & $(0.04)$ & & $(0.15)$ & $(0.02)$ \\
Winter 05/06 & 1.61 & 0.08 & & 2.01 & 0.04 \\
& $(0.54)$ & $(0.02)$ & & $(0.04)$ & $(0.01)$ \\
Annual 05/06 & $\mathbf{3 . 4 7}$ & $\mathbf{0 . 2 2}$ & & $\mathbf{3 . 1 0}$ & $\mathbf{0 . 1 6}$ \\
& $(\mathbf{0 . 3 3})$ & $(\mathbf{0 . 0 5})$ & & $\mathbf{( 0 . 0 2 )}$ & $\mathbf{( 0 . 0 3 )}$ \\
& & & & \\
Summer 06 & 1.10 & 0.20 & & 0.91 & 0.12 \\
& $(0.07)$ & $(0.01)$ & & $(0.03)$ & $(0.03)$ \\
Winter 06/07 & 1.42 & 0.06 & & 1.45 & 0.05 \\
& $(0.18)$ & $(0.01)$ & & $(0.08)$ & $0.01)$ \\
Annual 06/07 & $\mathbf{2 . 5 2}$ & $\mathbf{0 . 2 5}$ & & $\mathbf{2 . 3 6}$ & $\mathbf{0 . 1 7}$ \\
& $(\mathbf{0 . 1 7})$ & $(\mathbf{0 . 0 6})$ & $(\mathbf{0 . 0 7})$ & $(\mathbf{0 . 0 4})$ \\
& & & & \\
Summer 07 & 1.92 & 0.34 & 1.12 & 0.24 \\
& $(0.17)$ & $(0.09)$ & $(0.10)$ & $(0.08)$ \\
\hline
\end{tabular}


Table 3. Proportion of total litterfall [\%] by litter type and season at both study sites. Seasonal data are cumulative totals. Parenthesis contain standard error, $n=4$.

\begin{tabular}{lcccccc}
\hline & Needles & Leaves & Wood & Seeds & Cones & Understory \\
\hline Fir forest & & & & & & \\
$\quad$ Total & $50.6(1.8)$ & $6.0(2.1)$ & $32.0(2.7)$ & $7.9(1.9)$ & $0.3(0.1)$ & $3.2(0.5)$ \\
$\quad$ Winter & $50.9(2.3)$ & $0.3(0.1)$ & $37.8(4.7)$ & $3.9(2.1)$ & $0.7(0.4)$ & $6.5(1.2)$ \\
$\quad$ Summer & $51.5(4.2)$ & $9.7(4.0)$ & $27.0(3.3)$ & $10.5(1.5)$ & $0.0(0.0)$ & $1.2(0.3)$ \\
Fir clearcut & & & & & & \\
$\quad$ Total & $20.9(3.5)$ & $57.1(4.6)$ & $14.3(2.4)$ & $5.6(0.9)$ & $0.0(0.0)$ & $2.0(0.5)$ \\
$\quad$ Winter & $45.8(5.7)$ & $8.5(3.4)$ & $28.9(4.9)$ & $9.1(3.1)$ & $0.0(0.0)$ & $707(1.6)$ \\
$\quad$ Summer & $14.7(1.4)$ & $68.1(2.2)$ & $11.4(2.3)$ & $5.1(0.6$ & $0.0(0.0)$ & $0.7(0.3)$ \\
Spruce forest & & & & & & \\
$\quad$ Total & $51.2(1.4)$ & $0.3(0.1)$ & $37.0(2.3)$ & $8.6(1.0)$ & $0.5(0.2)$ & $2.3(0.2)$ \\
$\quad$ Winter & $53.3(2.3)$ & $0.1(0.0)$ & $36.1(2.3)$ & $5.7(0.9)$ & $1.0(0.5)$ & $3.8(0.3)$ \\
$\quad$ Summer & $49.1(1.3)$ & $0.6(0.2)$ & $37.9(3.0)$ & $11.7(2.1)$ & $0.0(0.0)$ & $0.7(0.1)$ \\
Spruce clearcut & & & & & & \\
$\quad$ Total & $15.8(8.1)$ & $43.3(13.1)$ & $31.2(7.1)$ & $8.7(3.0)$ & $0.0(0.0)$ & $1.0(0.2)$ \\
$\quad$ Winter & $19.6(7.1)$ & $7.4(3.5)$ & $56.2(8.6)$ & $12.2(6.8)$ & $0.0(0.0)$ & $4.6(1.4)$ \\
$\quad$ Summer & $15.4(8.3)$ & $48.3(14.2)$ & $27.2(6.7)$ & $8.6(2.8)$ & $0.0(0.0)$ & $0.4(0.2)$ \\
\hline
\end{tabular}

Table 4. Litterfall means and model statistics for litterfall at balsam fir and black spruce sites. Litterfall data were collected in May and November of 2006 and 2007 (data for 2005 were excluded due to the requirement for balanced data for the analysis). $P$ values are from ANOVA terms of mixed models, including fixed and random factors. Parentheses contain standard error, $\mathrm{n}=8$. Within treatment columns by litter type and species, non-significant differences (LSD test difference $(p<0.05)$ ) are indicated by means with the same bold letter.

\section{Litter Type}

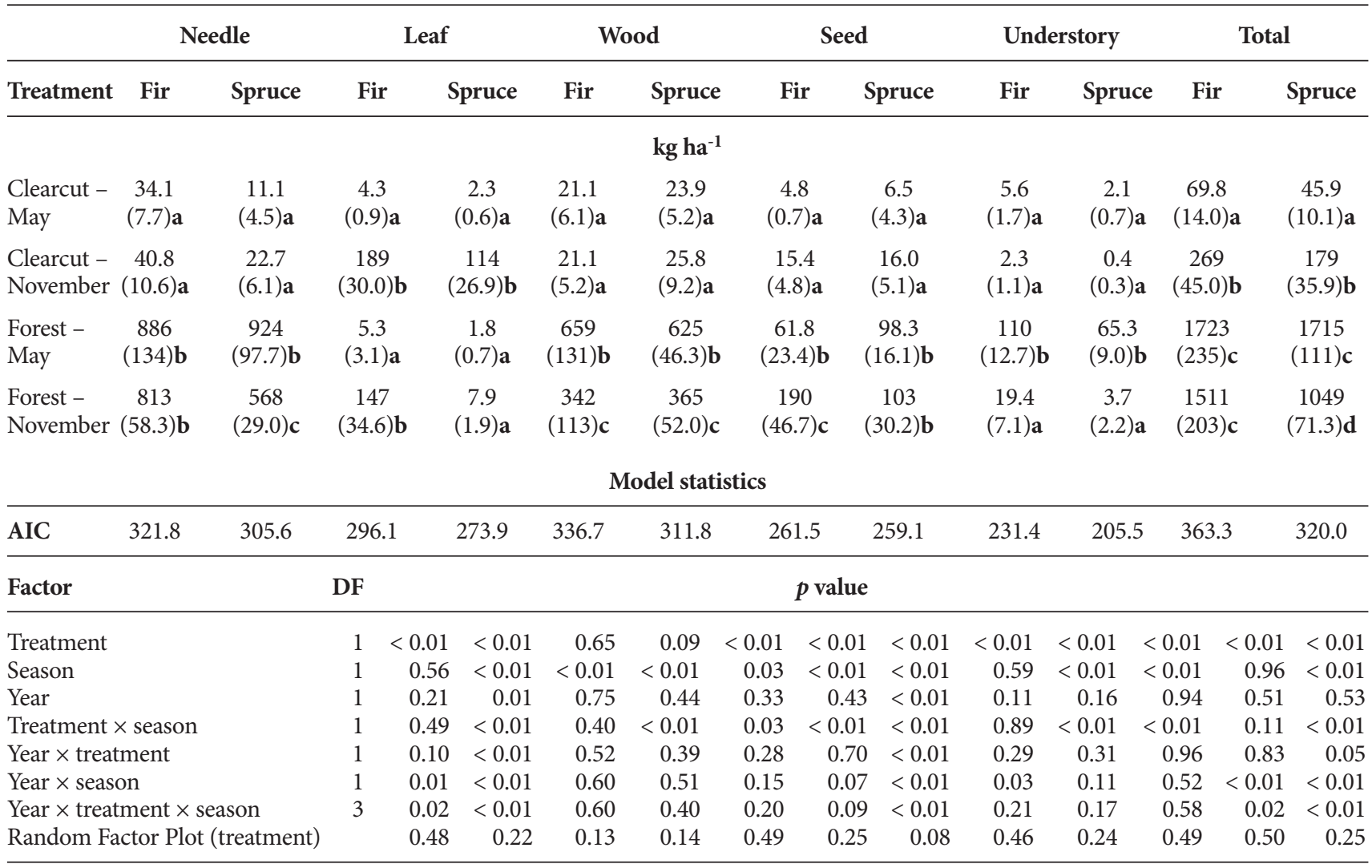

DF denotes degrees of freedom 
Table 6. Differences of least square means for the comparison of litter decomposition among clearcuts (CC) and forested (F) treatments and between fine roots and other litter types, from 2006-2008 litter bag collections for all litter types. Degrees of freedom = 24 for all comparisons. Significant differences $(p<0.05)$ between the pairs are shown in bold type.

\begin{tabular}{llrrrrr}
\hline & & \multicolumn{2}{c}{ Fir site } & & \multicolumn{2}{c}{ Spruce site } \\
\cline { 3 - 4 } \cline { 6 - 7 } Litter type and treatment & t-value & p-value & & t-value & p-value \\
\hline \multirow{2}{*}{ Fir needle C } & Root C & -1.43 & 0.17 & & -0.01 & 0.99 \\
Root C & Spruce needle C & -1.35 & 0.19 & & -0.97 & 0.34 \\
Moss C & Root C & $\mathbf{2 . 4 8}$ & $\mathbf{0 . 0 2}$ & & -1.24 & 0.23 \\
Root C & Roots F & 1.27 & 0.21 & & 0.66 & 0.51 \\
Fir needle F & Root F & 1.69 & 0.10 & & 1.27 & 0.22 \\
Root F & Spruce needle F & $\mathbf{- 4 . 0 1}$ & $<\mathbf{0 . 0 1}$ & & $\mathbf{2 . 1 9}$ & $\mathbf{0 . 0 4}$ \\
Moss F & Root F & $\mathbf{4 . 3 0}$ & $<\mathbf{0 . 0 1}$ & -0.28 & 0.78 \\
\hline
\end{tabular}

\section{Results}

Litterfall

Total litterfall was 2.5-3.5 $\mathrm{Mg} \mathrm{ha}^{-1}$ year-1 $^{-1}$ in fir and 2.4-3.1 Mg ha ${ }^{-1}$ year $^{-1}$ in spruce (Tables 2 and 4). Clearcutting reduced these rates to 0.2 $0.3 \mathrm{Mg} \mathrm{ha}^{-1}$ year $^{-1}$ in fir and $0.2 \mathrm{Mg} \mathrm{ha}^{-1}$ year $^{-1}$ in spruce. Litterfall in fir and spruce forests was dominated by needle and woody litter (Tables 3 and 4). In clearcuts, needle, wood and leaf litter dominated total litterfall, with leaf litterfall largely occurring in summer (May to November).

While there was no difference in total litterfall in fir forests between winter and summer, more total litter fell in winter than in summer under spruce forests (Table 4). More woody litter fell in winter. As expected from the deciduous component of the forests, more leaves fell in

ter type for the litter decomposition experiment). All statistical analyses were completed with SAS version 9.2. Prior to statistical analysis, proportional data were arcsine transformed. summer; however, the understory litter fell largely after the November collection. More needles fell in winter in spruce forests and seeds in summer under fir forests.

Table 5. At the balsam fir and black spruce sites in clearcut (CC) and forested (F) treatments a) Means and statistics for annual litter decomposition excluding fine roots (\% loss of dry weight) for the period of November 2003 to November 2008. b) Means and statistics for annual fine root decomposition (\% loss of dry weight) in balsam fir and black spruce sites for the period 2006-2008. ( $p$ values are from ANOVA terms of mixed linear models, including fixed and random factors. Parentheses contain standard error, $n=8$. Within unbroken columns, non-significant differences (LSD test difference $(p<0.05)$ ) are indicated by means with the same bold letter. Parentheses contain standard error, $n=8$ ).

\begin{tabular}{|c|c|c|c|c|c|c|c|}
\hline \multirow{4}{*}{$\begin{array}{l}\text { 5a Litter type and treatment } \\
\text { Fir needle CC }\end{array}$} & \multicolumn{3}{|c|}{ Site } & \multirow{3}{*}{\multicolumn{2}{|c|}{$5 b$ Litter type and treatmen }} & & \\
\hline & & & Spruce & & & Fir & \multirow[t]{2}{*}{ Spruce } \\
\hline & \multicolumn{3}{|c|}{$\%$ loss } & & & $\%$ loss & \\
\hline & \multicolumn{2}{|c|}{$14.6(2.2) \mathbf{a}$} & $16.8(1.8) \mathbf{a b}$ & Roots CC & \multicolumn{2}{|r|}{$12.8(1.5)$} & $14.5(1.8)$ \\
\hline Spruce needle CC & \multicolumn{2}{|c|}{$19.1(1.9) \mathbf{b}$} & $17.9(1.7) \mathbf{a b}$ & Roots F & \multicolumn{2}{|r|}{$9.9(1.0)$} & $12.3(0.7)$ \\
\hline Moss CC & \multicolumn{2}{|c|}{$19.6(2.8) \mathbf{b}$} & $16.9(2.8) \mathbf{a}$ & - & \multicolumn{2}{|r|}{-} & - \\
\hline Fir needle F & \multicolumn{2}{|c|}{$18.0(2.2) \mathbf{a b}$} & $19.3(2.2) \mathbf{b}$ & - & \multicolumn{2}{|r|}{-} & - \\
\hline Spruce needle F & \multicolumn{2}{|c|}{$22.1(2.3) \mathbf{b}$} & $20.6(2.1) \mathbf{b}$ & - & \multicolumn{2}{|r|}{-} & - \\
\hline \multirow[t]{2}{*}{ Moss F } & 21. & 9)b & $17.1(2.5) \mathbf{a b}$ & - & & - & - \\
\hline & \multicolumn{3}{|c|}{ Model statistics } & & \multicolumn{3}{|c|}{ Model statistics } \\
\hline AIC & \multicolumn{2}{|r|}{-103.2} & -111.3 & & \multicolumn{2}{|r|}{-34.3} & -52.8 \\
\hline Factor & \multicolumn{2}{|l|}{ DF } & $p$ value & & \multicolumn{2}{|l|}{ DF } & $p$ value \\
\hline Treatment & 1 & 0.07 & 0.18 & & 1 & 0.11 & 0.14 \\
\hline Litter Type & 2 & 0.02 & 0.04 & & $\mathrm{n} / \mathrm{a}$ & - & - \\
\hline Year & 4 & $<0.01$ & $<0.01$ & & 2 & 0.04 & $<0.01$ \\
\hline Treatment $\times$ litter type & 2 & 0.81 & 0.99 & & $\mathrm{n} / \mathrm{a}$ & - & - \\
\hline Year $\times$ treatment & 4 & 0.44 & 0.03 & & 2 & 0.96 & 0.02 \\
\hline Year $\times$ Season & 8 & 0.03 & $<0.01$ & & $\mathrm{n} / \mathrm{a}$ & - & - \\
\hline Year $\times$ season $\times$ litter type & 8 & 0.11 & 0.11 & & $\mathrm{n} / \mathrm{a}$ & - & - \\
\hline Random Factor Plot (treatment)- & - & 0.45 & - & & 0.48 & 0.44 & \\
\hline
\end{tabular}

DF denotes degrees of freedom 


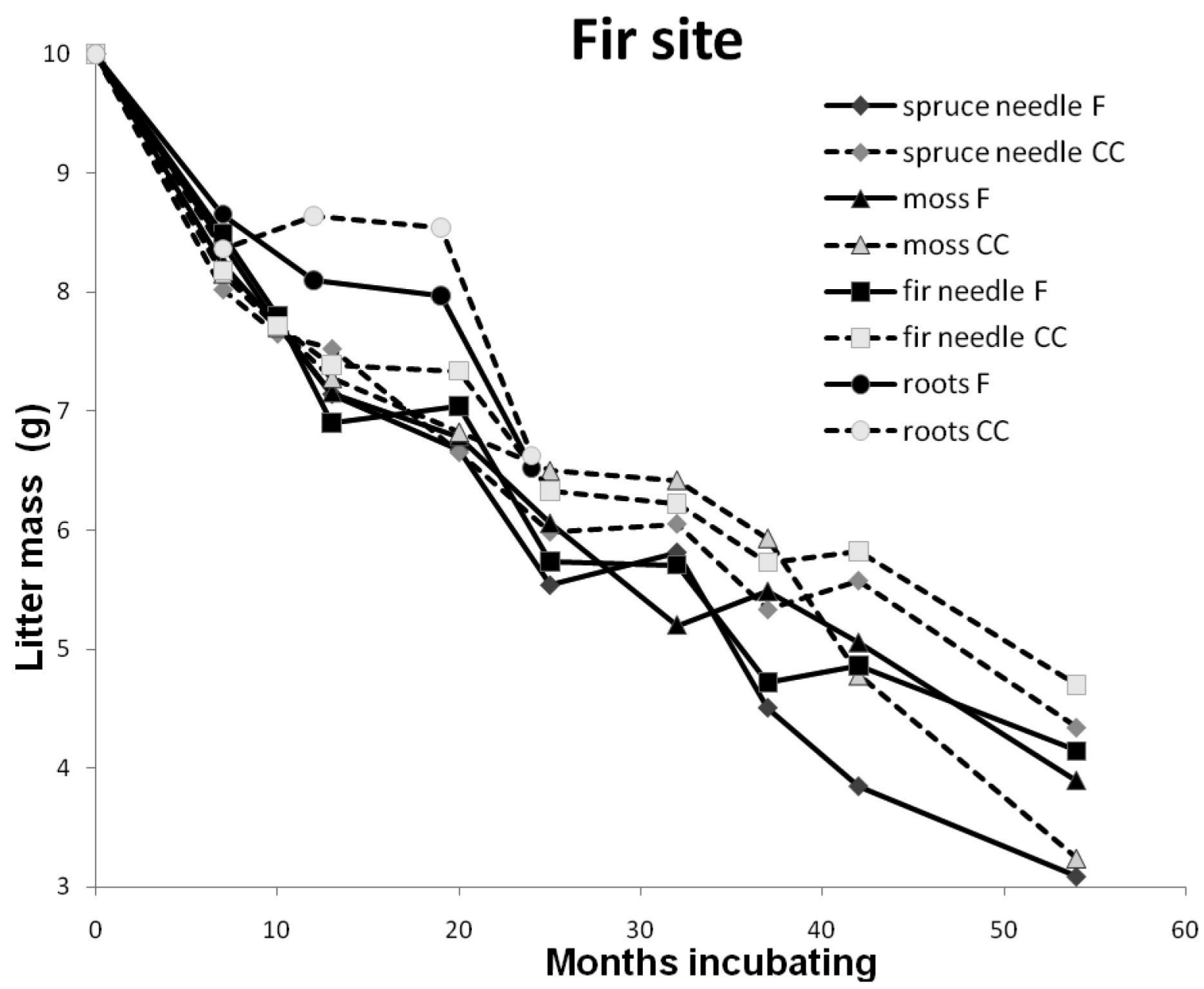

Fig. 1. Mass of litter remaining in litter bags with field incubation time at the balsam fir site; $n=4$. F denotes forested treatment and CC denotes clearcut treatment.

\section{Litter decomposition}

There was no effect of clearcutting on the rate of litter decomposition for any litter type over the study period (Table 5 and 6 , Figures 1 and 2). While there were no differences in moss or needle litter type decomposition in fir or spruce forests or in spruce clearcuts (Table 5, Figures 1 and 2), fir needles decomposed faster than spruce needles or moss in fir clearcuts.

Fine root field incubation was initiated two years later than for other litter types, creating an unbalanced experimental design. Root decomposition can be compared against the decomposition of other litter types when their data from 2005 to 2008 litter collections only are compared, balancing the experimental design among litter types. Thus, fine roots decomposed slower than moss under fir forests and slower than spruce needles in forests at both sites (Table 6). In clearcuts fine roots decomposed slower than moss at the fir site.

\section{Discussion}

Rates of litterfall in this study were similar to, or below, the 3.7 $\mathrm{Mg} \mathrm{ha}^{-1}$ average litterfall reported for evergreen forests in the northern hemisphere (Bray and Gorham 1964), and rates of litterfall in clearcuts were similar to those reported elsewhere for northern coniferous forests (Prescott et al. 1989). However, litterfall was more evenly distributed between summer and winter than reported elsewhere (Nakane et al. 1997, Prescott et al. 1989). Root turnover is comparable to rates of above-ground litterfall (Coleman and Crossley 1995, Vogt et al. 1996); hence, harvesting probably periodically interrupts 6 to $8 \mathrm{Mg} \mathrm{ha}^{-1}$ year $^{-1}$ of litter cycling.

Rates of litter decomposition were within the range reported for similar litter types across Canada (Trofymow et al. 2002). There were no differences in rates of mass loss between forests and clearcuts for any litter type. Difference in rates of mass loss between litter types within treatment were fir needles decomposed slower than spruce needles and moss in fir clearcuts (Table 5, Figure 1 and 2) and that fine root decomposition was slower than moss in fir and spruce needles under fir and spruce forests. Slower decomposition of fine roots may have resulted from field incubation at the mineral and organic soil interface, which was cooler than the surface where other litters were incubated. The effect of litter quality on decomposition is most pronounced during the first years of decomposition (Trofymow et al. 2002), indicating that moss and nee- 


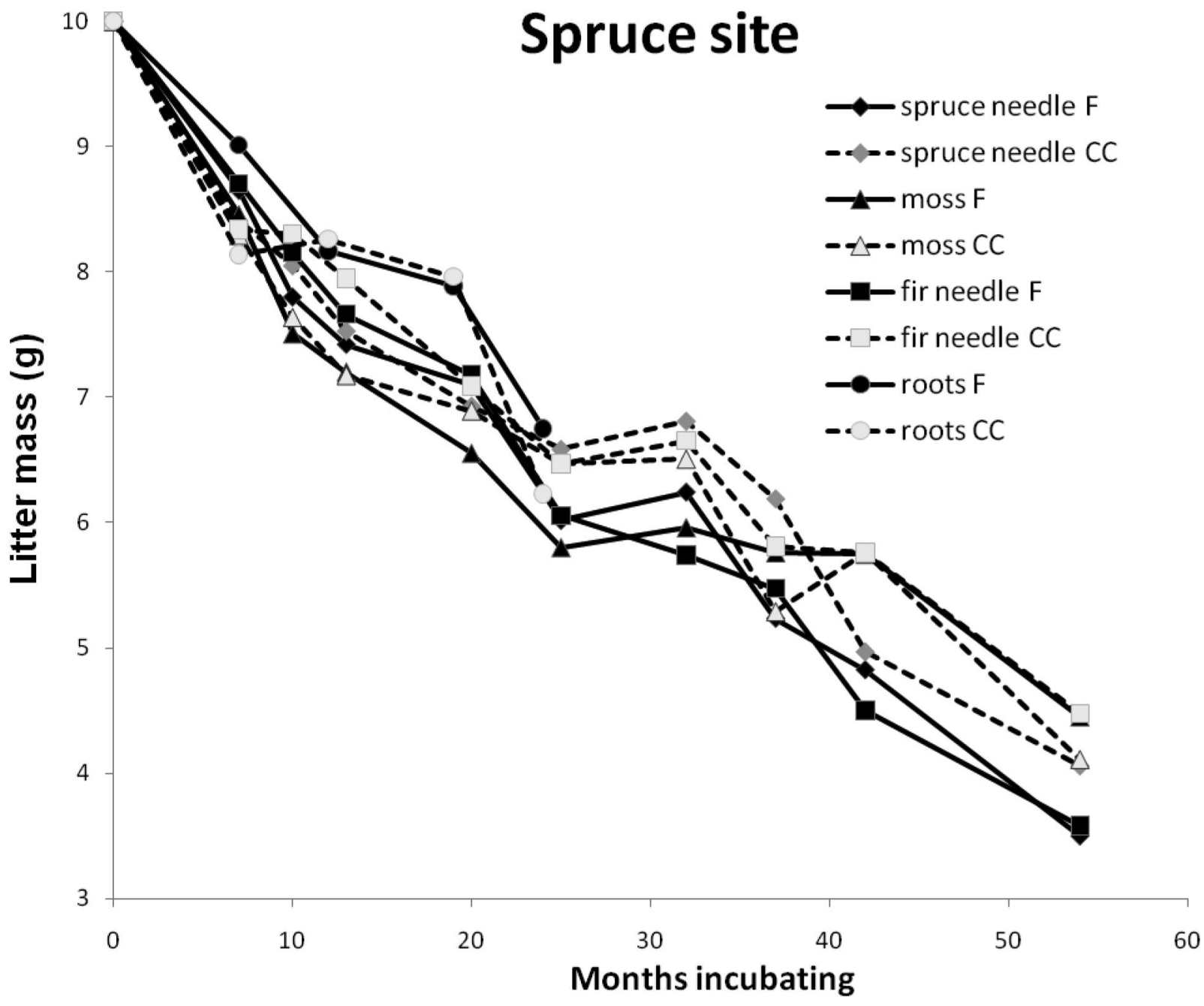

Fig. 2. Mass of litter remaining in litter bags with field incubation time at the black spruce site; $n=4$. F denotes forested treatment and CC denotes clearcut treatment.

dles were of a similar quality, suggesting that the moss litter was of a relatively high quality in this forest setting.

Forest harvesting usually increases soil temperatures due to increased exposure to incident solar radiation (Barg and Edmonds 1999). At our study sites clearcutting increased soil temperatures by $\sim 2^{\circ} \mathrm{C}$ during summer when compared to forested plots (Moroni et al. 2009), which is expected to increase rates of litter decomposition. However, despite an annual precipitation of $1250 \mathrm{~mm}$ to $1320 \mathrm{~mm}$, being among the highest for the North American boreal forest (Foster 1985), Moroni et al. (2009) found evidence for surface drying inhibiting soil respiration. Of published examinations of forest harvesting on litter decomposition that we located (Table 1 ), rates of litter decomposition in clearcuts were more often not increased than increased, even though soil temperatures were probably increased in most cases. Thus, increases in litter decomposition from increased temperatures in clearcuts in this study and others were likely masked by litter drying, even in cool, high-rainfall environments.

Fine roots decomposed at similar rates in forests and clearcuts (Table 5) despite incubation at the organic and mineral soil interface where some warming occurred and drying, which can significantly restrict decomposer activity, is less likely than at the surface (Moroni et al. 2009). The lack of an enhanced fine root decomposition following clearcutting is thus unexpected, indicating soil conditions were not limiting rates of fine root mass loss. Root decomposition in this study followed patterns observed for other litter types, as observed elsewhere (Berg 1984). Early decomposition is regulated by nutrient content or labile soluble material, strongly influenced by leaching. Latter stages of decomposition are more strongly influenced by more complex molecules such as lignin and polyphenols (Finer et al. 1997, Preston et al. 2009). Thus, rates of soluble material leaching from fine roots rather than temperature and moisture effects on decomposition potentially limited initial (zero to two-year) fine root decay in this study. This may also apply to the other litter types we examined since all appeared to have a similar rates of decay, unaffected by changes in soil moisture and temperature regimes between clearcut and forest treatments (Moroni et al. 2009). 
In contrast to wetland conditions, moss decomposed relatively quickly in the studied upland forests. Moss forms an almost continuous ground cover in many boreal forests (Bisbee et al. 2001) where feathermosses often dominate (De Luca et al. 2002). The growing moss layer often represents a large proportion of site net primary productivity (O'Connell et al. 2003) and can contain large live biomasses (Harden et al. 1997) that overlay a large amount of decomposing moss and plant tissue (Sparrow et al. 1992). Clearcutting often results in a gradual death of the moss layer (Bock and van Rees 2002, Fenton et al. 2003) because bryophytes are sensitive to low ground-level humidity and intense solar radiation (Keenan and Kimmins 1993). Since the intact bryophyte layer reduces O-horizon temperature and nutrient availability, while increasing O-horizon moisture levels and acidity (Bisbee $e t$ al. 2001) decomposition of the organic layer is slowed (Hagemann et al. 2010). Hence, following harvesting large quantities of labile bryophyte material are potentially added to the detrital pool and the decomposition of organic material accelerated as the preservation qualities of an active bryophyte layer are diminished. Thus, effects of harvesting on the bryophyte layer are potentially important to nutrient and carbon cycles in forests with extensive moss cover, such as many coniferous and boreal forests.

\section{Conclusion}

Rates of litterfall and litter decomposition in wet eastern Canadian black spruce and balsam fir forests were similar to rates reported for northern coniferous systems. Forest clearcutting significantly reduced rates of overstory litterfall by $2.2 \mathrm{Mg} \mathrm{ha}^{-1}$ year $^{-1}$ to $3.3 \mathrm{Mg} \mathrm{ha}^{-1}$ year $^{-1}$. Even in a cool wet forest, where surface drying and associated limitations on decomposition are expected to be minimal following harvesting, litter decomposition in forests and clearcuts were similar, indicating that moisture and temperate regimes in uncut and clearcut forests are not limiting rates of decomposition. Moss decomposition was similar to needle and fine root decomposition, indicating that the bryophyte layer produces labile litters in forests.

\section{Acknowledgements}

Thanks to Corner Brook Pulp and Paper and the Newfoundland Forest Service for the provision of the experimental sites and for performing the required harvests. Thanks to Darrel Harris, Shelley Garland, Rebecca Dodd, Leanne Morgan, Blaine Park, Vicky Cormier, and David Decker for sample collection and preparation.

\section{References}

Agren, G.I., B. Axelsson, J.G.K. Flower-Ellis, S. Linder, H. Persson, H. Staaf and E. Troeng. 1980. Annual carbon budget for a young scots pine. Ecological Bulletins 32: 307-313

Barg, A.K. and R.L. Edmonds. 1999. Influence of partial cutting on site microclimate, soil nitrogen dynamics, and microbial biomass in Douglas-fir stands in western Washington. Can. J. For. Res. 29: 705-713.

Berg.B. 1984. Decomposition of root litter and some factors regulating the process: long term root decomposition in a Scots pine forest. Soil Biology and Biochemistry 16: 609-618.

Binkley, D. 1984. Does forest removal increase rates of decomposition and nitrogen release. Forest Ecology and Management 8: 229-233
Blair, J.M. and D.A. Crossley Jr. 1988. Litter Decomposition, Nitrogen Dynamics and Litter Microarthropods in a Southern Appalachian Hardwood Forest 8 Years Following Clearcutting. Journal of Applied Ecology 25: 683-698.

Bisbee, K.E., S.T. Gower, J.M. Norman, and E.V. Nordheim. 2001. Environmental controls on ground cover species composition and productivity in a black spruce boreal forest. Oecologia 129: 261-270. Bock, M.D. and K.C.J. van Rees. 2002. Forest harvesting impacts on soil properties and vegetation communities in the Northwest Territories. Can. J. For. Res. 32: 713-724.

Bray, J.R. and E. Gorham. 1964. Litter production in forests of the world. Advances in Ecological Research 2: 101-157.

Coleman, D.C. and D.A. Crossley Jr. 1995. Fundamentals of Soil Ecology. Academic Press, San Diego. 205 p.

Cortina, J., and V.R. Vallejo. 1994. Effects of clearfelling on forest floor accumulation and litter decomposition in a radiata pine plantation. Forest Ecology and Management 70: 299-310.

De Luca, T.H., O. Zackrisson, M. Nilsson and A. Sellstedt. 2002. Quantifying nitrogen-fixation in feather moss carpets of boreal forests. Nature 419: 917-920.

Diekamp, M. 2009. Moss and lichen decomposition in old-growth and recently harvested high-boreal black spruce (Picea mariana) forest stands in Labrador, Canada. Masters dissertation, Faculty of Forestry, Dresden University of Technology.

Ecoregions Working Group. 1989. Ecoclimate regions of Canada. Ecol. Land Class. Series No. 23. Environment Canada, Canadian Wildlife Service, Ottawa. 118 p., map.

Fenton, N.J., K.A. Frego and M.R. Sims. 2003. Changes in forest floor bryophyte (moss and liverwort) communities 4 years after forest harvest. Can. J. Bot. 81: 714-731.

Finer, L., C. Messier and L. De Grandpre. 1997. Fine root dynamics in mixed boreal conifer-broad-leafed forest stands at different successional stages after fire. Canadian Journal of Forest Research 27: 304-314.

Fissore, C., C.P. Giardina, C.W. Swanston, G.M. King and R.K. Kolka. 2009. Variable temperature sensitivity of soil organic carbon in North American forests. Global Change Biol. 15: 2295-2310.

Foster, D.R. 1985. Vegetation development following fire in Picea mariana (black spruce) - Pleurozium forests of south-eastern Labrador, Canadian Journal of Ecology 73: 517-34.

Fyles, J.W. and W.B. McGill. 1987. Decomposition of boreal forest litters from central Alberta under laboratory conditions. Canadian Journal of Forest Research 17: 109-114.

Gadgil, R.L. and P.D. Gadgil. 1978. Influence of clearfelling on decomposition of Pinus radiata litter. New Zealand Journal of Forest Science 8: 213-234.

Hagemann, U., M.T. Moroni, J. Gleißner and F. Makeschin. 2010. Accumulation and preservation of dead wood upon burial by bryophytes. Ecosystems 13: 600-611.

Harden, J.W., K.P. O'Neill, S.E. Trumbore, H. Veldhuis and B.J. Stocks. 1997. Moss and soil contributions to the annual net carbon flux of a maturing boreal forest. Journal of Geophysical Research 102: 28805-28816.

Hobbie, S.E. 1996. Temperature and plant species control over litter decomposition in Alaskan tundra. Ecological Monographs 66: 503-522.

Hobbie, S.E., J.P. Schimel, S.E. Trumbore and J.R. Randersons. 2000. Controls over carbon storage and turnover in high-latitude soils. Global Change Biology 6: 196-210.

Howard, E.A., S.T. Gower, J.A. Foley and C.J. Kucharik. 2004. Effects of logging on carbon dynamics of a jack pine forest in Saskatchewan, Canada. Global Change Biology 10: 1267-1284.

Keenan, R.J. and J.P. Kimmins. 1993. The ecological effects of clear-cutting. Environ. Rev. 1: 121-144.

Klemmedson, J.O., C.E. Meier and R.E. Campbell. 1985. Needle decomposition and nutrient release in Ponderosa pine ecosystems. Forest Science 31: 647-660. 
McKenney, D.W., J.L. Kesteven, M.F. Hutchinson and L. Venier. 2001. Canada's plant hardiness zones revisited using modern climate interpolation techniques. Can. J. Plant Sci. 81: 139-143.

Moroni, M.T., P.Q. Carter and D.A.J. Ryan. 2009. Harvesting and slash piling affects surface respiration, soil temperature, and soil moisture regimes in Newfoundland boreal forests. Canadian Journal of Soil Science 89: 343-355.

Nakane, K., T. Kohno, T. Horikoshi and T. Nakatsubo. 1997. Soil carbon cycling at a black spruce (Picea mariana) forest stand in Saskatchewan, Canada. Journal of Geophysical Research 102: 28785-28793.

[NLDFRA] Newfoundland Department of Forest Resources and Agrifoods. 1998. 20-year forestry development plan 1996-2015. NLDFRA, NL For. Serv., St. John's, NL.

O'Connell, K.E.B., S.T. Gower and J.M. Norman. 2003. Comparison of net primary production and light-use dynamics of two boreal black spruce forest communities. Ecosystems 6: 236-247.

Piene, H. and K. van Cleve. 1978. Weight loss of litter and cellulose bags in a thinned white spruce forest in interior Alaska. Canadian Journal of Forest Research. 8: 42-46.

Prescott, C.E., L.L. Blevins and C.L. Staley. 2000. Effects of clearcutting on decomposition rates of litter and forest floor in forests of British Columbia. Canadian Journal of Forest Research 30: 1751-1757.

Prescott, C.E., J.P. Corbin and D. Parkinson. 1989. Input, accumulation, and residence times of carbon, nitrogen, and phosphorus in four Rocky Mountain forests. Canadian Journal of Forest Research 19: 489-498.

Prescott, C.E., B.R. Taylor, W.F.J. Parsons, D.M. Durall and D. Parkinson. 1993. Nutrient release from decomposing litter in Rocky Mountain coniferous forests: influence of nutrient availability. Canadian Journal of Forest Research 23: 1576-1586.

Preston, C.M., J.R. Nault and J.A. Trofymow. 2009. Chemical changes during 6 Years of decomposition of 11 litters in some Canadian forest sites. Part $2 .{ }^{13} \mathrm{C}$ Abundance, Solid-State ${ }^{13} \mathrm{C}$ NMR Spectroscopy and the Meaning of "Lignin". Ecosystems 12: 1078-1102.

Rowe, J.S. 1972. Forest regions of Canada. Can. For. Serv., Dept. Environ., Ottawa.

Schuting and Christman. 1935. Ueber die Abbau von Auflagehumus bei Waldboden III Humusabbau and Kahlschlag. Mitteilungen aus Forstwirtschaft Forstwissen Forstwissen Schalt. Pp. 425-446.

Sparrow, S.D., E.B. Sparrow and V.L. Cochran. 1992. Decomposition in forest and fallow subarctic soils. Biology and Fertility of Soils 4: $253-259$
Szumigalski A.R. and S.E. Bayley. 1996. Decomposition along a bog to rich fen gradient in central Alberta, Canada. Canadian Journal of Botany 74: 573-581.

Tarnocai, C., J.G. Canadell, E.A.G. Schuur, P. Kuhry, G. Mazhitova and S. Zimov. 2009. Soil organic carbon pools in the northern circumpolar permafrost. Global Biogeochemical Cycles. 23: GB2023, doi: 10.1029/2008GB003327. 11 p.

Taylor, B.R., C.E. Prescott, W.J.F. Parsons and D. Parkinson. 1991. Substrate control of litter decomposition in four Rocky Mountain coniferous forests. Canadian Journal of Botany 69: 2242-2250.

Thormann, M.N., S.E. Bayley and R.S. Currah. 2001. Comparison of decomposition of belowground and aboveground plant litters in peatlands of Boreal Alberta, Canada. Canadian Journal of Botany 79: 9-22.

Trofymow, J.A. et al. 2002. Rates of litter decomposition over 6 years in Canadian forests: influence of litter quality and climate. Canadian Journal of Forest Research 32: 789-804.

Vogt, K.A., C.C. Grier and D.J. Vogt. 1986. Production, turnover, and nutrient dynamics of above- and below-ground detritus of world forests. Advances in Ecological Research 15: 303-377.

Vogt, K.A., D.J. Vogt, P.A. Palmiotto, P. Boon, J. O'Hara and H. Asbjornsen. 1996. Review of root dynamics in forest ecosystems grouped by climate, climatic forest type and species. Plant and Soil 187: 491-494.

Wallace, E.S. and B. Freedman. 1986. Forest floor dynamics in a chronosequence of hardwood stands in central Nova Scotia. Canadian Journal of Forest Research 16: 293-302.

Weetman, G.F. 1965. The decomposition of confined black spruce needles on the forest floor, Woodlands Research Index 165. Pulp and Paper Research Institute of Canada, Montreal. 18 p.

Whitford, W.G., V. Meetemeyer, T.R. Seastedt, K. Cromack, D.A. Crossley, P. Santos, R.L. Todd and J.L. Waide. 1981. Exceptions to the AET model; deserts and clearcut forest. Ecology 62: 275-277.

Will, G.M., P.D. Hodgkiss and H.A.I. Madgwick. 1983. Nutrient losses from litterbags containing Pinus radiata litter: Influences of thinning, clearfelling, and urea fertiliser. New Zealand Journal of Forestry Science 13: 291-304.

Yin, X., J.A. Perry and R.K. Dickerson. 1989. Influence of canopy removal on oak forest floor decomposition. Canadian Journal of Forest Research 19: 204-214. 